\title{
Implementation of Pancasila Values In Civil Society Participation Against Covid-19
}

Bimo Aryo Nugroho, Universitas Indonesia, bimoouw@gmail.com

Margaretha Hanita, Universitas Indonesia, margaretha.hanita@gmail.com

\section{ABSTRAK}

Covid-19 pandemic significantly affects the community's social life. It does not only result in a health crisis but also an economic crisis. This condition requires a collaboration between the governments and the community as national integration. Recent political situation exhibits a decrease in the tense relationship between the state and the civil society. A transformation is necessary to compromise. Accordingly, the state and civil society should cooperate, help each other, and control each other. Pancasila, as an open ideology, should be implemented as a national life guideline to obtain the state goals amid this pandemic.

KEYWORDS: Implementation, Pancasila, Civil Society

\section{BACKGROUND}

In 2020, the world faces coronavirus outbreak. Firstly reported in Wuhan, this virus spread all over the world. Accordingly, the World Health Organization (WHO) declares the Covid-19 a pandemic. Historically, Coronavirus has caused three diseases in the last two decades, namely SARS, MERS, and Covid-19. The first two viruses (i.e., SARS in 2002 and MERS in 2012) have escalated the global emergency status. Covid-19 is similar to 
SARS and MERS in terms of its carrier agent, transmission pattern, and symptoms. Covid-19 has infected 4,255,940 people, out of that number, 1,522,034 people are recovered and 287,332 people were reported dead $^{1} \mathrm{In}$ Indonesia, since 2 March 2020, the first covid-19 case was reported, on 12 May 2020, 14,557 positive cases were reported. While 3062 patients were recovered, 1007 patients were reported dead. ${ }^{2}$ Based on the number reported above, the case fatality rate due to Covid-19 in Indonesia is still below 10\%. However, the most dangerous aspect of this virus is its rapid spread, requiring countries around the world to put great effort to handle the spread before the vaccine is found.

In preventing the spread of Covid-19, WHO and countries around the world apply social distancing policy. This policy is implemented at different levels in each country. Some of them implement lockdown, while the others implement mobility restriction, as Indonesia does with its Large-Scale Social Distancing (PSBB). Attempts made in cutting the spread of the virus affect the economic sector. Thus, Indonesia and the world today does not only face a health crisis but also face economic crisis. In the formal sector, as of 16 April 2020, 229.789 employees were terminated, while 1,270,367 employees

\footnotetext{
${ }^{1}$ Artikel Update 12 Mei di Dunia: Kasus COVID-19 Naik Jadi 4,2 Juta", https://tirto.id/frdp

${ }^{2}$ Artikel ini telah tayang di Kompas.com dengan judul "UPDATE: Kini Ada 14.749 Kasus Covid-19 di Indonesia, Bertambah 484", https://nasional.kompas.com/read/2020/05/12/15531531/update-kiniada-14749-kasus-covid-19-di-indonesia-bertambah-484.
} 
were laid off due to the pandemic. ${ }^{3}$ The present economic crisis is potentially similar to that occurred in 1998.

This pandemic is proven to affect all layers of the community. Accordingly, national integration is required to address both national and global challenges caused by the Covid-19 pandemic. Howard Wriggins, as cited in Andi Aco Agus's study, mentions five factors that determine the national integration of a country, namely: 1. Foreign threats, 2. Political style, 3. Strength of Political Institutions, 4. Ideology, 5. Opportunity to Economic development. ${ }^{4}$ As a state philosophy, Pancasila provides vision and guidelines to achieve the vision. Hence, the implementation of Pancasila values is crucial to obtain national integration during this pandemic.

During the 1998 economic crisis, agitation driven by civil society resulted in a political transition. Civil society, in this case, was youth organizations, plays significant roles in Indonesia, starting from struggling for independence, defending the independence, and regime transition of the country. These movements are driven by Indonesian youth intellectuals, including university students. The history witnesses that most of the drivers of a movement are students who are active in organizations. Organizations are important for the youth because it provides space to learn knowledge outside the classroom wall. Organizations help students develop their insight, knowledge, aptitude,

\footnotetext{
${ }^{3}$ Total 1,9 Juta Pekerja Di-PHK dan Dirumahkan akibat Pandemi Virus Corona, https://www.kompas.com/tren/read/2020/04/19/081000465/total-19-juta-pekerja-di-phk-dandirumahkan-akibat-pandemi-virus-corona.

${ }^{4}$ Andi Aco Agus, “Integrasi Nasional Sebagai Salah Satu Parameter Persatuan dan Kesatuan Bangsa Negara Republik Indonesia". Jurnal Sosialisasi Pendidikan Sosiologi FiS UNM, 2016
} 
and interest. Besides, it helps them find their identity. While the 1998 economic crisis made civil society confronts the government, this pandemic requires the collaboration of all parties, both the government and the community. Civil society holds a strategic position to play roles in helping the community and the government during this pandemic. Within such collaboration, Pancasila values, as the state philosophy, could be used as a guideline of national life during the economic crisis.

\section{DISCUSSION}

\section{A. Position of Civil Society within a Country}

In some literature on Civil society, civil society is associated with Antonio Gramsci's work. Gramsci argues that Civil society is a non-state actor or non-government organization aiming at establishing a historical block to address the state's arbitrariness using its hegemony. Argues wrote this argument when Fascism dominated Italy. At that time, Italians were rising to free from the state's control and violence to create their own history. Gramsci's idea is supported by many scholars, one of them was Ernest Gellner (1981) who defined civil society as a non-government actor whose power is equal to that of a country but not aimed to challenge the country. Another definition is proposed by John Hall (1995) who argues that civil society does not take issue with the state's role as an entity that is authorized to guarantee its citizen's welfare and order; Instead, it aims to prevent the state from performing excessive domination over its citizen. 
In the Indonesian context, civil society shares the same purpose as Indonesia's founding fathers, i.e., towards Indonesia's socialism. Civil society contains a range of concepts and meanings, Afan Gaffar (1999) highlights the concept of civil society as space, meaning that it serves as a space for individuals and groups of the community to interact within the spirit of pluralism and tolerance. In addition to interaction, the community is also allowed to participate in the policy-making processes. In other words, civil society is a space between the state and the community that contains voluntary associations among the community. The nature of this community association is independent and could not be intervened by the state and power. Accordingly, Einstadt (as cited in Muhammad AS Hikam, 1996) concludes that civil society is a community order where individuals and groups interact with tolerance and are independent. Furthermore, Einstadt (as cited in Muhammad AS Hikam, 1996) states that autonomy, access to the public interest and state institution, and state-intervention, open, free public area are required to establish civil society.

Another view on the relationship between the state and civil society is proposed by Arato and Cohan (1994), they stated that Civil society is a community formed within a country, whose social system, economic status, and political attitude could not be intervened by the state. In other words, civil society demands a public area that provides the community with freedom, while the state only acts as a night-watchman state (nachwachterstaat) of the interaction done by the community. 
Recent political situation exhibits a decrease in the tense relationship between the state and civil society. According to Giddens (2002), transformation is necessary to compromise. The state and civil society should cooperate, help each other, and control each other. To promote changes, a framework that involves collaboration between the government and civil society, the improvement of local initiatives; civil society involvement; public space protection; community-based crime prevention; and establishment of democratic family.

The importance of civil society involvement in a political decision-making process, which initially existed only in the relationship between the state and market, indirectly transforms the configuration of national life. Relation between the government, market, and civil society is asserted by the World Bank within the spirit of good governance. ${ }^{5}$ Civil society is an autonomous organization (in terms of profession, belief, religion, issue, class, identity) separated from political power structures. This organization element possesses varied names, particularly in Indonesia. ${ }^{6}$

\section{B. Historical Review on Pancasila as the State Philosophy}

Pancasila was born from long ideological warfare, it is initially a reflection of Soekarno's view regarding the nation's life. Pancasila is not Soekarno's original idea. The conception of Pancasila had lived before he presented his views on the state foundation and ideology in the BPUPKI session. The

\footnotetext{
${ }^{5}$ Masimo De Angelis,dkk, petaka neoliberalisme. (Malang: Intrans Publishing 2016) h.1

${ }^{6}$ Aljihad, Sadam. Pancasila Ideologi dunia.
} 
initial ideas of Pancasila could also be found in the conception of Perhimpunan Indonesia's ideology in 1924. According to PI, the purpose of political independence should lie in four principles, namely national unity, solidarity, non-cooperation, and autonomy. These principles are closely associated with the direction of struggle shown by Indische partij, Communist movements, and Sarekat Islam. ${ }^{7}$

In his speech, Soekarno acknowledged that the idea of Pancasila had lived long since Hinduism and the pre-Hinduism era, which was crystallized into five points. These five points are: Pancasila, according to Soekarno, is the crystallization of all values living in Nusantara. These five principles include 1.Nationality, 2. Internationalism, or Humanity, 3. Democracy, 4. Social Welfare, and 5. Cultured divinity. Soekarno called these principles "Panca Sila." Based on these principles, Indonesia is established. ${ }^{8}$

The state foundation named Pancasila by Soekarno was accepted by acclamation by the members of BPUPKI, which was then improved together to make it more systematic. To this end, before the first session ended, a small council was established to formulate the state foundation based on Soekarno's speech on 1 June 1945 and BPUPKI members' views during the first session. This small council consisted of eight members led by Soekarno. During the formulation process, however, Soekarno formed another small council to accelerate the formulation of the state foundation. This small

\footnotetext{
7 lbid.

8 Soekarno, Pantja Slla Sebagai Dasar Negara, (Kursus Presiden Sukarno di Istana Negara tahun 1958) bagian II, h.8 -15
} 
council consisted of nine members, known as Panitia Sembilan. Panitia Sembilan's work was known as Jakarta Charter. On 18 August 1945, PPKI conducted another session. At that time, an amendment was made in the fourth paragraph of the 1945 preamble by deleting the phrase "obligation to perform Islamic sharia for the adherents."

During the reform era, the existence of Pancasila as a source of law is stipulated through TAP MPR no. III/MPR/2000 on Source of law and the Order of Regulatory Legislation. However, this TAP MPR does not explicitly state that Pancasila serves as the source of law in the national legal system. Accordingly, Law no. 10 of 2004 on The Formulation of Regulatory Legislation is issued to assert the standing of Pancasila as the source of law.

\section{Implementation of Pancasila Values In Civil Society Participation Against}

\section{Covid-19}

In this research, Himpunan Mahasiswa Islam (HMI) plays a role as a civil society organization, HMI is an organization consisting of well-educated, critical, and professional students who are expected to serve as agents of changes. HMI cadres should be able to adapt to the social environment and analyze as well as solve the problems found. To implement this value, HMI explicitly regulates this in its article of the organization (AD/ART). As explained before, HMI aims to deliver Islamic, responsible academics, creators, devotees to create a fair, welfare community blessed by Allah. HMI

\footnotetext{
${ }^{9}$ Dalam Piagam Jakarta, sila pertama Pancasila berbunyi "Ketuhanan, dengan kewajiban menjalankan syari'at Islam bagi pemeluk-pemeluknya". Setelah dicoret tujuh kata itu maka jadilah "Ketuhanan Yang Maha Esa". Lihat Mohammad Hatta dkk, ibid, h.77
} 
could not ensure that its members will possess qualification as stated above. Instead, every member should put efforts to achieve the organization's goal. The target of the HMI movement is Indonesian citizens. HMI desires for welfare, just, and a well-educated community who is capable of thinking rationally. With regard to this purpose, a benchmark is set, including 1 . Community with a high education level, who is insightful, able to think critically, and rationally. 2. Community who possesses theoretical ability so that they could behave with full awareness. 3. Community who is autonomous and possesses strength identity so that they are not easily influenced by other people or other nations.

As a part of civil society, HMI carrying out its function in line with the public purpose. As the informant of the study stated, HMI's public goal is to build a nation with the purpose stated in article 4 and 5 of its article of organization. HMI is a civil society categorized as a youth organization. During the Covid-19 pandemic, HMI performs its function as the government's partner. For HMI, Pancasila and Islam are not contradictory, it agrees with Indonesia's founding fathers who state that Pancasila is consistent with Islamic teachings.

During the covid-19 pandemic, HMI collaborates with various elements of the community and the government to handle the pandemic. The participations are done in the form of social crowdfunding, educating the community, and controlling public policies. In carrying out its role, HMI utilizes its elements and organizational structure. It possesses 225 branches 
in the entire Indonesian territory. It is the largest and oldest Islamic student organization in Indonesia.

HMI's social aid is given at every level, from the central level to the regional level. At the central level, HMI conducted crowdfunding. The fund is used to help communities affected by Covid-19, it is also used to buy medical equipment for medical institutions handling Covid-19. It is done because, at the beginning of the pandemic, many medical workers find it difficult to find the required medical equipment, such as PPE and face masks. The shortage of medical equipment was the result of the huge demands of PPE in Indonesia. Besides, it was also due to hoarding committed by some people. Besides buying PPE, the fund obtained was also used to buy staple foods and distributed to the affected community.

HMI also educated the community through online media. The education was in the form of socialization to be discipline during PSBB and education related to the covid-19 pandemic. With regard to the social control, HMI performs control toward the government's policies in handling the Covid-19 pandemic. It was done not only in the form of criticism but also ideas that helpful for the government in handling Covid-19.

\section{CONCLUSION}

Based on the description above, that HMI uses Islamic values which are also contained in the values of Pancasila, especially in the handling of Covid-19, namely in the first precept, the supreme deity, Islamic values contained 
therein, in terms of its application, it can be interpreted that Islam also teaches cooperation with others mankind, or in the interpretation of Pancasila, it is defined as mutual cooperation, which is the sharing of bones together, one for all and all for one as a way to face the Covid-19 pandemic.

The implementation of Pancasila values in HMI's participation as civil society in addressing the covid-19 pandemic is applied along with the Islamic values. It was done because HMI believes that Pancasila is in line with Islam. HMI agrees with the founding fathers who state that Pancasila values are consistent with Islamic values. HMI's participation in handling this pandemic is divided into three categories, namely social aid, community education, and public policy control. HMI, as a civil society, does not only act as the balancer but also as a bridge between the community and the government.

\section{BIBLIOGRAPHY}

Artikel Update 12 Mei di Dunia: Kasus COVID-19 Naik Jadi 4,2 Juta", https://tirto.id/frdp

Artikel ini telah tayang di Kompas.com dengan judul "UPDATE: Kini Ada

14.749 Kasus Covid-19 di Indonesia, Bertambah 484", https://nasional.kompas.com/read/2020/05/12/15531531/updatekini-ada-14749-kasus-covid-19-di-indonesia-bertambah-484.

Total 1,9 Juta Pekerja Di-PHK dan Dirumahkan akibat Pandemi Virus Corona,https://www.kompas.com/tren/read/2020/04/19/081000465 
/total-19-juta-pekerja-di-phk-dan-dirumahkan-akibat-pandemivirus-corona.

Andi Aco Agus, "Integrasi Nasional Sebagai Salah Satu Parameter Persatuan dan Kesatuan Bangsa Negara Republik Indonesia”. Jurnal Sosialisasi Pendidikan Sosiologi FiS UNM, 2016

Masimo De Angelis,dkk, petaka neoliberalisme. (Malang: Intrans Publishing 2016) h.1

Aljihad, Sadam. Pancasila Ideologi dunia.

Soekarno, Pantja Sila Sebagai Dasar Negara, (Kursus Presiden Sukarno di Istana Negara tahun 1958) bagian II, 